Heymons, R. '97. Entwicklungsgeschichtliche Untersuchungen an Lepisma saccharina L. Zeits. wiss. zool. bd. 62.

Huxley, T. H. '77. A Manual of the Anatomy of Invertebrated Animals.

Kolbe, H. J. '89-'93. Einführung in die Kenntnis der Insekten.

Miall, L. C. and Denny, A. '86. The Structure and Life-history of the Cockroach.

Packard, A.S.'7r. Embryological Studies on Diplax, Perithemis, and the Thysanurous Genus Isotoma. Mem. Peab. acad. sc. no. 2. Packard, A. S. '98. A Text-book of Entomology.

Sharp, D. '95. Insecta. Camb. nat. hist.
Uzel, H. '97. Vorläufige Mittheilung über die Entwicklung der Thysanuren. Zool. anz. bd. 20.

Uzel, H '98. Studien tuber die Entwicklung der apterygoten Insecten. Berlin.

Vayssière, A. '82. Recherches sur l'organization des larves des Éphémérines. Ann. sc. nat. zool. sér. 6, t. I3.

Viallanes, A. '87. Etudes histologiques et organologiques sur les centres nerveux et les organes des sens des animaux articulés, Ann. sc. nat. zool. sér. 7, t. 4 .

Wheeler, W. M. '93. A contribution to Insect Embryology. Jour. morph. vol. 8.

\title{
DESCRIPTIONS OF THREE NEW SPECIES OF ALEURODIDAE FROM BRAZIL.
}

BY ADOLPH HEMPEL, S. PAULO, BRAZIL.

Aleurodes horridus n. sp. - Pupa-case.Length, I mm.; elliptical in outline, flat; light yellow in color. The dorsal surface is covered with white secretion, arranged in a median longitudinal row, and a submarginal row on each side. Around the margin there is also a very short fringe of white wax. These details are however obscured by a mass of long yellowish, hair-like secretion, that envelopes each individual. Denuded of wax, the margin is found to be doubly crenulated, with the posterior end of the body rounded and the anterior end forming an obtuse angle. The dorsum is slightly wrinkled, and has a short median longitudinal ridge, extending from the anterior end to nearly the middle of the body.

Vasiform orifice subelliptical, broader than long. Operculum hemispherical, nearly fitting the orifice, the free end notched. A long seta is situated on each side of the orifice; two on the caudal end of the body; and two on the ventral surface of the body just cephalad of the middle. No traces of antennae or legs were found.
Adult \%.- $1.08 \mathrm{~mm}$. long, yellow, eyes black; wings transparent, yellowish, covered with a white powder. Antennae of seven joints. Joints $3-7$ fine, cylindrical, slender; joint 2 large, club-shaped. Legs long and slender, nearly reaching to the apex of the closed wings.

$H a b$. - On the underside of leaves of guava, Psidium sp., from S. Paulo, Brazil. Accompanied by a species of ant (Cremastogaster).

Aleurodes fumipennis n. sp.-Pupa-case.Elliptical, convex, black, $1.8 \mathrm{~mm}$. long. There is a prominent median longitudinal, dorsal ridge, and about six transverse furrows. The lateral margin is thick with a conspicuous groove on the dorsal surface, and a short fringe of white wax on the ventral surface. Near the posterior end, around the vasiform orifice, there is a large hemispherical area, nearly transparent, but dusted with white secretion. The lateral margin is slightly notched in places, but not crenulated. Vasiform orifice hemispherical; operculum small, rectangular, fitting the 
orifice. Around the lateral margin there is a row of about 32 sharp sword-like hairs. A long seta is situated on each side of the orifice, and on the ventral surface, near the posterior end there are a pair of short setae. The remains of the legs and antennae can be seen on the ventral surface.

Adult \%.-Brown; eyes large, black; length $1.63 \mathrm{~mm}$. Antennae of seven joints; joint 2 large, club-shaped; joint 3 very long; joints 4-6 short, cylindrical, equal in length; joint 7 about half the length of joint 3 . Wings large with the basal half and portions of the rest of the wing smoky.

$H a b$. On the underside of leaves of grass growing on swampy ground, S. Paulo, Brazil. It is also accompanied by a species of ant (Camponotus).

Aleurodes parvus n. sp. - Pupa-case.Small, flat, black, oval; .94 mm. long; usually enveloped in a mass of white felt- like hairy secretion. Dorsum with a longitudinal median ridge, and several transverse furrows. Marginal edge thickened, with a double row of crenulations. Vasiform orifice hemispherical. Operculum small, hemispherical, not filling the orifice. A long seta is situated on each side of the orifice. A pair of short setae extend caudad from the posterior part of the body; and another pair are situated on the ventral surface just cephalad of the middle.

Adult +.-Body very light yellow, eyes black; length .90 $\mathrm{mm}$. Wings transparent, dusted with a white powder. Antennae short, slender, of seven joints. Joint 2 large club-shaped; joints 3-7 small cylindrical.

$H a b$. - On the under side of leaves of Maytenus sp. S. Paulo, Brazil.

S. Paulo, Brazil, May 15, 1896 .

\title{
LIFE HISTORIES OF NORTH AMERICAN GEOMETRIDAE. - III.
}

\author{
BY HARRISON G. DYAR, WASHINGTON, D. C.
}

Eutrapela (Selenia) alcipheraria Walk. - The eggs were kindly sent me by Miss Caroline G. Soule from Woodstock, Vermont. The moth which I bred was determined by Dr. Hulst. The larva is not previously described to my knowledge.

Egg. Regularly elliptical from top view, the surface flattened, but obliquely; outline somewhat wedge-shaped from the side, the top slightly hollowed. Surface shagreened not reticulated, shining. Dimensions $.4 \times \mathrm{I}$ $\mathrm{mm}$. Green when laid, dark red when received and finally black just before hatching.

Stage $I$. Thick and stout black Geometrids, the abdominal feet normal. Head bilobed, brown-black with pale setae; width about $.5 \mathrm{~mm}$. Body all dark velvety brown, the abdominal and anal leg plates bright red, contrasting; four tiny yellow dorsal dots (paired oval light areas on the posterior edges of segments 5 and 7 which are not tubercles). Tubercles conic, distinct, but concolorous; setae short, dark, normal, with slightly swollen tips. Anterior edge of cervical shield and mouth reddish. The larvae drop by a thread on being disturbed and twist up into a knot.

Stage II. Head about $.8 \mathrm{~mm}$ wide; all dark vinous black as before, but the little bright paired dots are supplemented by a fainter pair on joint 8 and tubercle $i$ of joints 5 to 9 is produced into a rounded prominence. Head rounded, clypeus pale.

Stage III. Head rounded, brown with a short and thick black band on each lobe; width $1.2 \mathrm{~mm}$. Tubercle $i$ on joints 5 to 9 is high and subpapillose; white dots on joints 6 and 7 anteriorly. Body still largely brown, but diversified with gray in dorsal and subdorsal diffuse and dotted bands on joints 5 to 

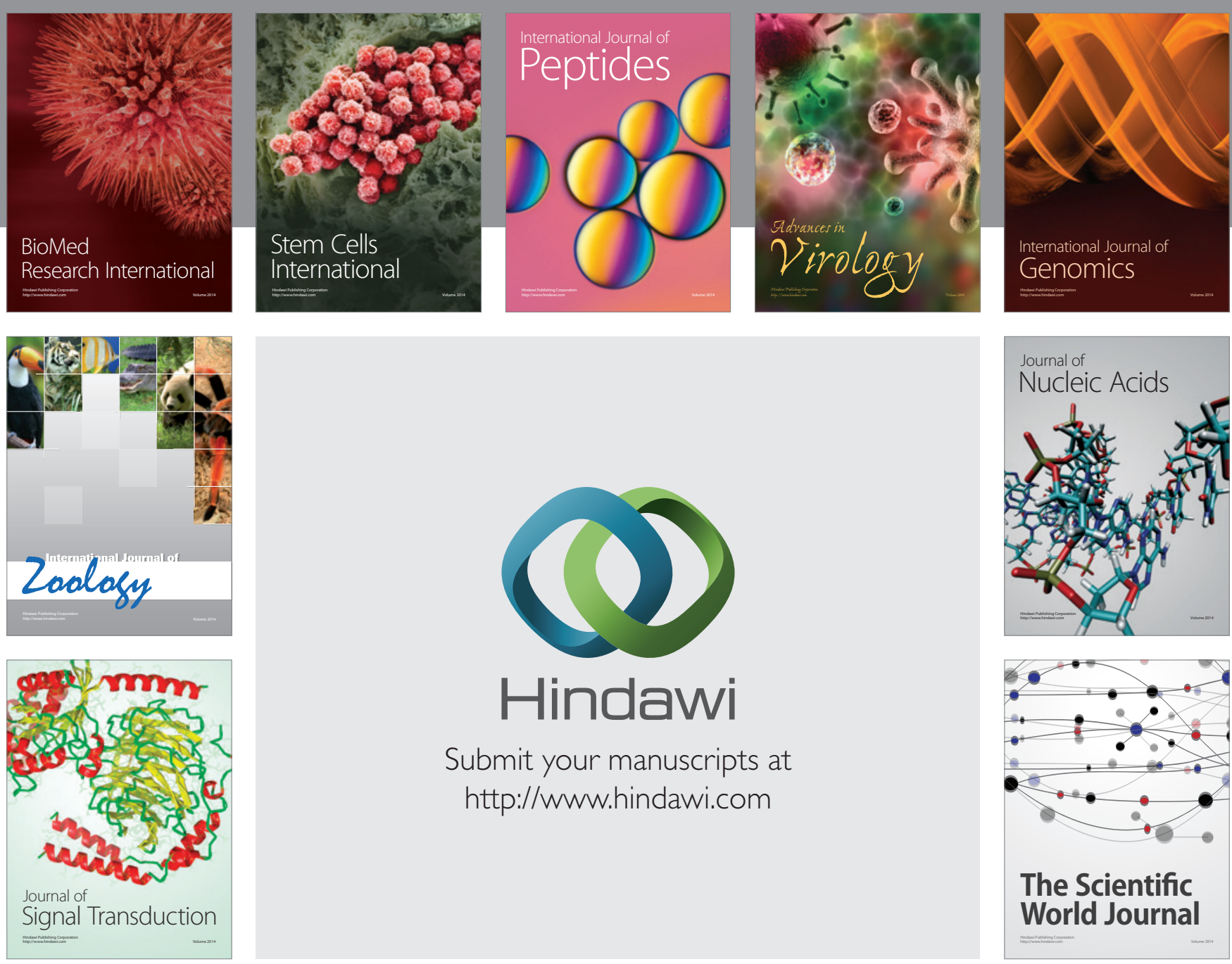

Submit your manuscripts at

http://www.hindawi.com
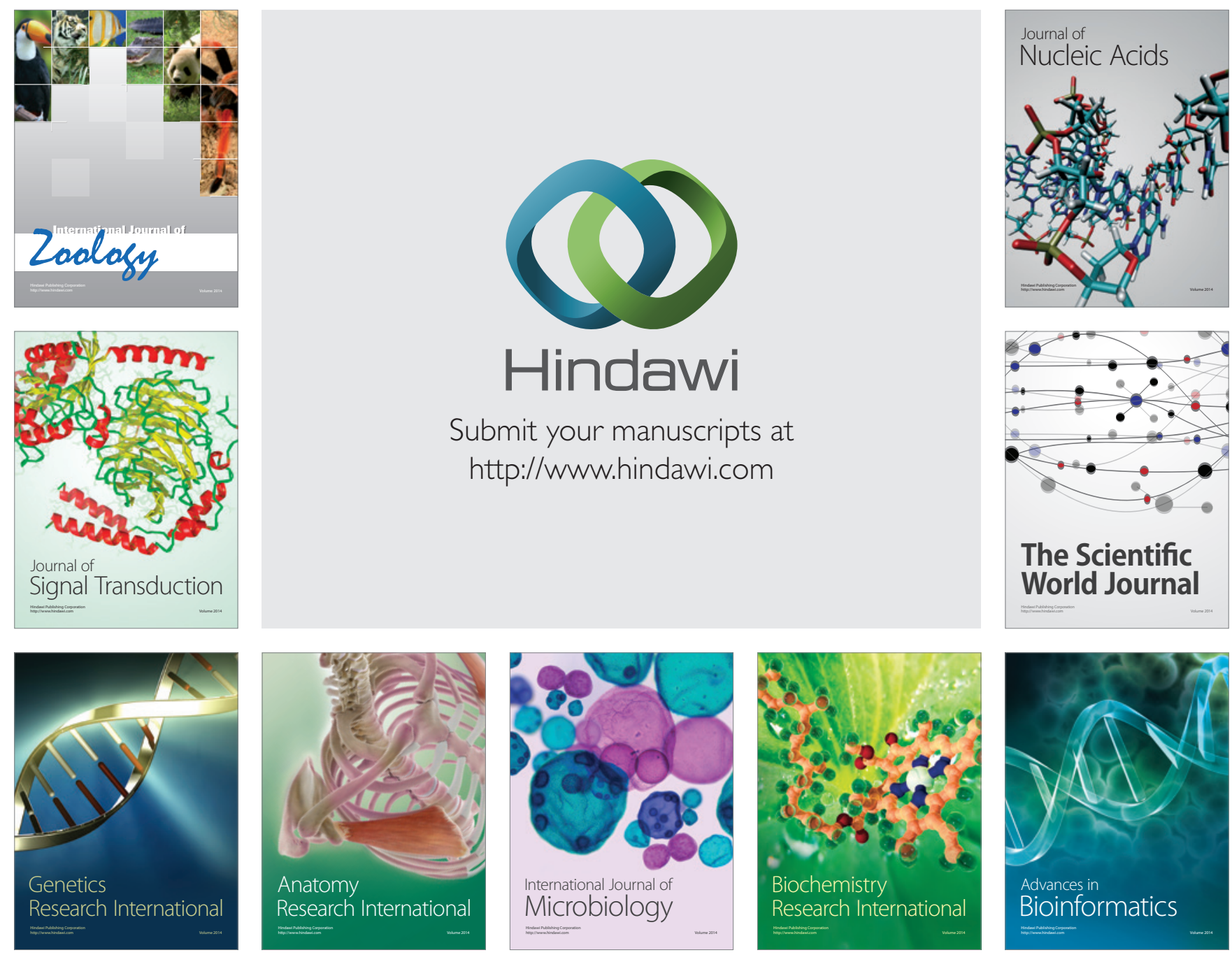

The Scientific World Journal
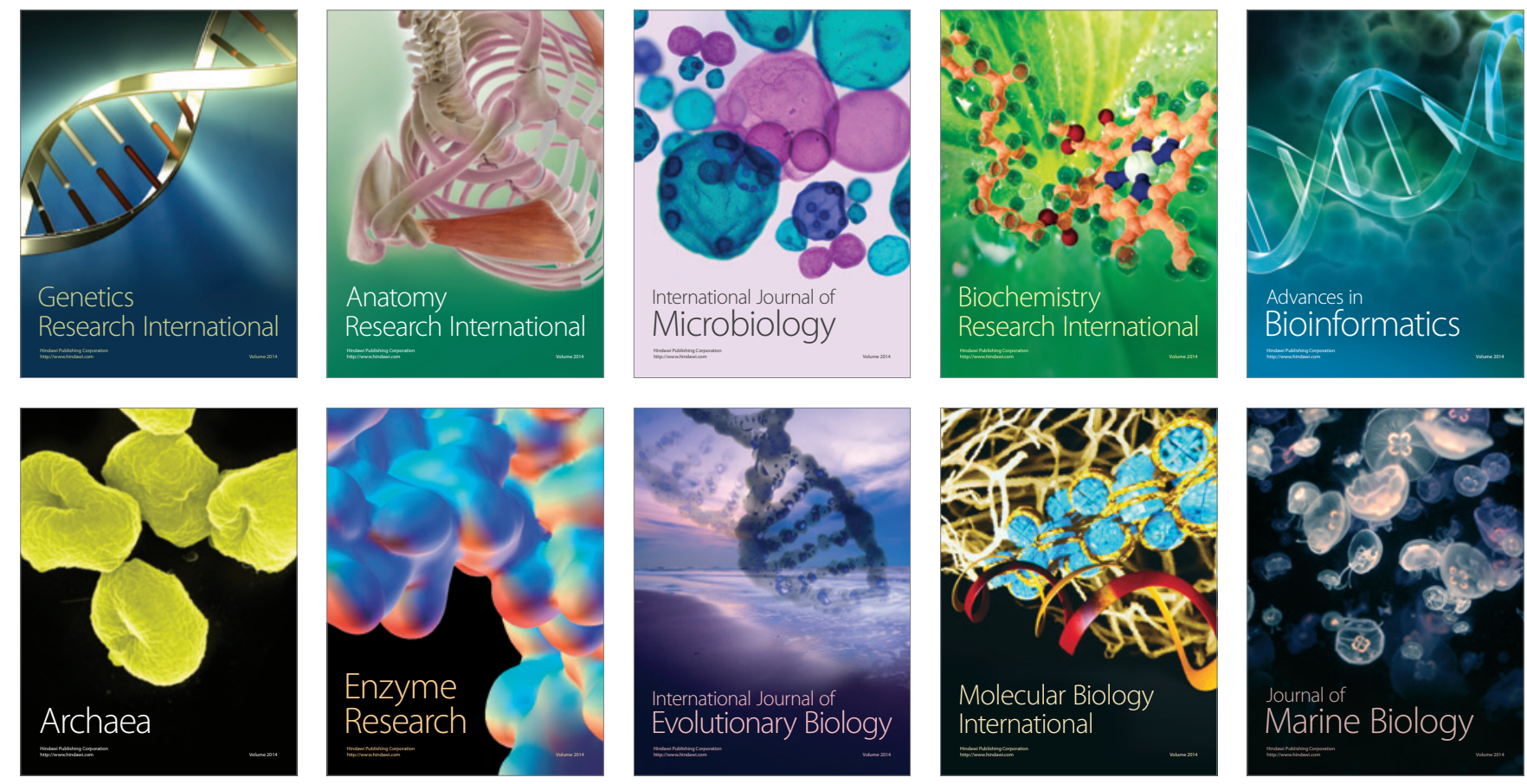